\title{
The Rebels: Luba Derczanska and Her Friends
}

Among the sources in the Hamied family archive is a strip of celluloid containing a short amateurish film that had been shot in Berlin in the summer of 1932. Its flickering black-and-white images show a slender woman with a stylish beret perched on the side of her head, self-consciously posing in front of Berlin's most famous sites. These are the earliest moving images of Luba Hamied, born Liubov Derczanska, whom her mother nicknamed Hinde (the Indian) and whom her husband called 'a modern Russian woman'. The camera follows her under the lush trees of the Lustgarten, between the colonnades of the Alte Museum and onto the steps of Haus Vaterland, the famous pleasure palace on Potsdamer Platz. Her husband Khwaja Abdul Hamied is at her side. He is a clean-shaven young Indian gentleman with a beaming face; he is dressed in a suit and tie and has a large Borsalino hat on his head. We see him asking directions from a policeman in the centre of Potsdamer Platz, where he buys his wife a bouquet of flowers from a street vendor in front of the Tietz department store. Election posters are fluttering from balconies all around them. This election will presage Hitler's rise to power and will be the last German election until the Nazi regime is defeated. The political atmosphere does not, however, seem to touch the couple. They have just returned from Bombay to revisit the city of their love and they look blissfully happy. A square black Mercedes with sideboards had been waiting at the pavement for the couple and, as Hamied elegantly opens the door for his wife, she speaks silently to the cameraman. In the last shot we see her frowning and raising her hand in an authoritative gesture, as if to say, 'enough!' With that, the filmstrip breaks off. ${ }^{1}$

This chapter is about Luba Derczanska. Arriving in Berlin in 1925 to study chemistry at Berlin University, she became caught up in the Indian freedom struggle, not least through meeting Hamied, the man she would marry in the Berlin mosque and follow to India. Whereas Lisa Oettinger, the subject of Chapter 4, was from a secular Prussian Jewish background, for which experimenting with art, religion and different men came naturally, Luba Derczanska was from a traditional Jewish family. Her parents spoke Yiddish at home, visited the synagogue regularly, followed strict rules about child rearing, and valued family loyalty above all else. In the city of Vilna (now Vilnius), which hostile forces invaded no fewer than 13 times between the First and Second World

1 'Old Family Film Part 1', Hamied private archive, Mumbai. 
Wars, which changed between Russian, German, Lithuanian and Polish rule as the armies came and went, and in which communist and nationalist loyalties often tore families apart, it required considerable strength to remain united, and her tumultuous childhood left a clear mark on Luba's life.

\section{A Jewish Girl from Vilna}

Liubov Derczanska was born on 28 February 1903 in Vilna, at that time still part of imperial Russia. She was the eldest of four siblings and her education was typical of that of any upwardly mobile Jewish family - first the Hebrew primary school (Cheder), then the Russian imperial secondary school for girls, followed by a year's teacher training. ${ }^{2}$ This was a path that many Russian Jewish women had already taken in preparation for higher studies in Moscow or St Petersburg. ${ }^{3}$ However, by the time Liubov finished in 1920, the city had become part of the new Lithuanian nation-state and the medium of instruction in her school had changed from Russian to Lithuanian. This bestowed upon her a linguistic training that included not only Russian, but also Lithuanian, German, Polish and Latin. Nevertheless, the Russian career path her parents envisioned for her had evaporated.

Liubov Derczanska was a Russian speaker with a Russian Jewish identity. Like many young Jews around her, once Russia changed from imperial to Bolshevist rule, she sided with the communists. However, the Red Army occupied the city only for a short period, and left it to the Lithuanians to set up a government. A civil war followed in which Vilna changed hands again and became part of Poland. ${ }^{4}$ Embracing a nationalist worldview, the new Polish nationstate felt threatened by the communists, so accordingly fought them. From then on, life was precarious for the Jews who had embraced the Russian cause in Vilna. ${ }^{5}$ The Derczanska family felt the strain. Rubin and Pauline Derczanska

2 Hamied private archive, Marina Suzman collection.

3 Sophia Dubnow enrolled in the 'Bestushev Higher Courses for Women' in Saint Petersburg in 1903 and Nadeshda Krupskaya in 1887. Both authors offer a lively description of other women in the classroom. See Sophie Dubnov-Erlich, The Life and Work of S.M. Dubnov: Diaspora, Nationalism and Jewish History (Bloomington: Indiana University Press, 1991); Nadeshda Krupskaya, Memories of Lenin (London: Panther Books, 1970).

4 Theodore R. Weeks, From 'Russian' to 'Polish': Vilna-Wilno 19oo-1925, NCEEER, Working paper, 2006.

5 Jaff Schatz, The Generation: The Rise and Fall of the Generation of Jewish Communists of Poland (Berkeley: University of California Press, 1991); Jaff Schatz, 'Jews and the communist movement in interwar Poland', in Jonathan Frankel and Dan Diner (eds) Dark Times, Dire Decisions:Jews and Communism (Oxford: Oxford University Press, 2004), 13-37. 
formed part of the liberal minded Jewish middle class. A furrier by profession, Rubin ran a successful shop selling furs and hats on one of the city's main thoroughfares, ${ }^{6}$ which most certainly would have suffered during the Polish occupation, in which 2000 Jewish shops were smashed and plundered. ${ }^{7}$ However, he was not a man to be easily discouraged and, making a fresh start, began to conduct business at the Leipzig Fair. ${ }^{8}$ In a later communist party file on his daughter Fania, he is described as 'a petty bourgeois'. ${ }^{9}$ His daughters Liubov, Fania (b. 1905) and Lenka (b. 1910), by contrast, joined the revolutionary youth, the young Russian Jews who believed in the promise of communist equality that would do away with discrimination against Jews, and they set out along their life paths accordingly. ${ }^{10}$

In 1923, Liubov Derczanska acquired a Polish passport, which enabled her to go abroad. Her parents wanted her to leave town, desist from the activities in which she was engaged and enrol at the Academy for Jewish Studies (Hochschule für die Wissenschaft des Judentums) in Berlin..$^{11}$ They saw that as a safe option and her father set about making the preliminary arrangements. A document, drawn up by the secretary of a branch of the academy in Vilna assured her of a place at the school for 1924/5. Rubin Derczanska wrote a letter claiming financial responsibility for his daughter during her stay in Berlin and her

$6 \quad$ His business letters read: 'Dertschansky, Wilno, Rudnikastr. 2. Pelzwarenhandlung und Hutmanufaktur' (Furs and hat manufacture), Hamied private archive, Marina Suzman collection.

7 When the Polish army occupied Vilnius for the first time in 1919, it attacked the Jewish population on account of its Russian (communist) sympathies, killing intellectuals, rampaging the Choral synagogue, and smashing over 2000 Jewish shops in the city centre. Henry Morgenthau Sr, 'Mission of the United States to Poland/American Commission to Negotiate Peace/Mission to Poland', Paris, 3 October 1919. Internal Report of the American Commission, 4.

8 Hamied private archive, Marina Suzman collection.

9 Comintern Archive in the Russian State Archive of Social and Political History (RGASPI)/ Akte Derczanska, Fania (Léna) 1933-38, 11.

10 Zvi Y. Gitelman, A Century of Ambivalence: The Jews of Russia and the Soviet Union, 1881 to the Present (New York: YIVo Institute of Jewish Research, 1988), 96 ff.; Igal Halfin, Red Autobiographies: Initiating the Bolshevik Self (Washington: University of Washington Press, 2011), 97-157; Yuri Slezkine, The Jewish Century (Princeton: Princeton University Press, 2006), 105-203, 175-8.

11 The Hochschule für die Wissenschaft des Judentums was founded in 1872 as part of the Haskalah, the Jewish Enlightenment. In the 1920s it offered a thorough training in Bible, Talmud and history, languages and religious philosophy, reflecting the place of German Jews in Germany. It also produced the first ever female rabbis. Irene Kaufmann, Die Hochschule für die Wissenschaft des Judentums, 1872-1942 (Berlin: Hentrich \& Hentrich, 2006). 
mother Pauline wrote to her sister Bertha, who was already living in Berlin, to ask her to keep an eye on her. ${ }^{12}$

All this is merely leading up to the point of this chapter, which is about the entanglement of 'a modern Russian woman'13 from a discriminated against minority in central Europe in a group of Indians and Germans living in Berlin. In this chapter, which covers no more than eight years, I reconstruct the Jewish network that helped her settle in Berlin, recount the details of how she and Abdul Hamied met and look at how he and his friends were received in her neighbourhood. Luba essentially assumed the role of mediator between her communist and nationalist associates, between her Indian friends and her Jewish landladies, between her Jewish family in Vilna and her Muslim family in India and, later in life, between Russia and the young Indian nation-state.

There are many and varied sources on which to base the narrative. At the end of his life, Khwaja Abdul Hamied wrote his memoirs and took several other steps to secure his legacy. These are consulted, though addressed in more detail in the next chapter. Luba herself saved a cache of $65^{\circ}$ letters, which she kept in plastic folders in her cupboard and which were found after her death in 1991. Because the letters were written in German, Russian, Polish and Yiddish, which were languages that her children did not know, their value only came to light later. Mumbai's hot, humid climate had almost destroyed them, but once removed from the plastic folders and safely preserved between acid-free sheets of paper in the Hamied family archive, they were given to me to read when I visited. My astonishment at their contents must have been apparent, for it aroused the family's curiosity. The communication that followed provided the basis for this chapter.

The letters proved to be a veritable treasure trove. Apart from offering insights into the couple's meeting in Berlin, they yielded information on the comings and goings in the Indian Bureau, the Indian revolutionary organization in Berlin discussed in Chapter 2. More importantly, the letters highlight the inclusion of Jews in the Indian network. They, along with Luba's personal documents, film reels and family photographs, as well as information from other archives, provide ample evidence on which to build her story.

Incidentally, before she arrived in Berlin, Luba had already begun to free herself from her parents' guidance. A document with a Kaunas (Kovno) University letterhead and drafted in Lithuanian states that 'Dercanskaite, Liuba, studied in the faculty of mathematics and physics for the winter term of $1924 / 5$,

12 Hamied private archive, Marina Suzman collection.

13 This is how Abdul Hamied called her from their early days of courtship, and she loved him dearly for that. Hamied private archive, DO-2015-11-03-45. 
where she attended courses in zoology, inorganic chemistry, physics, mineralogy, and histology'.14 Although her parents wanted her to study Jewish theology and become a religious teacher, Luba's own passion lay in experimental biology. In spring 1925 she left Kaunas again, this time in the direction of Berlin. There is a second witness of her time there, for among her letters is a piece of experimental prose, written by Zacharias Shuster, and dated 1924. A young Yiddish writer, Shuster was part of the vibrant Yiddish scene in Kaunas, where he published the avant-garde journal Di Yidishe Stime (The Yiddish Voice). ${ }^{15}$ The piece is splattered with inkblots, and strokes through the sentences attest to a work in progress, but it nonetheless becomes clear that the author was trying to depict three women students from Vilnius, the three Vilnerkes, as he nicknamed them. His portrayal of Luba marks the beginning of her trajectory, no longer the obliging daughter, but also not yet the woman of the world she portrays in the film eight years later:

The second one is slender, the darkest of the three. A face fashioned like a marble. Serious, in unexpected encounters all of a sudden shut up, like a small flower. ... Does not flirt, but who knows her dreams? Up to her ears in learning, as if she wants to reach her goal before the others. ... Speaks Russian, but her Yiddishkeit beckons to you in her every movement. ${ }^{16}$

If anything, Shuster's description managed to capture her determination. For the rest of her life, she kept that document in her trove.

\section{$2 \quad$ Russian Berlin}

In the period between the First World War and the Second World War, secular internationalist utopias thrived. Workers, heads of state, scientists, anarchists,

14 'Atestas', Hamied private archive, Suzman collection.

15 Anon, 'Autobiographical sketch of Zacharias Shuster', American Jewish Committee, 7 March 1966, internal document; Sarunas Liekis, A State within State? Jewish Autonomy in Lituania 1918-1925 (Vilnius: Versus Aurus, 2003); Sarunas Liekis, 'Jüdische Autonomie in Litauen. Unabhängigkeit einer Minderheit und das Wesen des sozialen Experiments', in Elke-Wera Kotowski and Julius H. Schoeps (eds) Vilne. Wilna. Wilno. Vilnius. Eine jüdische Topographie zwischen Mythos und Moderne (Berlin: Hentrich \& Hentrich, 2017), 41-55.

16 Zacharias Shuster, 'Di Drei'. Kaunas, 1924. Hamied private archive, DO-2015-11-06-01. Translation from the Yiddish by Sophie Lichtenstein. 'Yiddishkeit' is something like the essence of being Yiddish. 


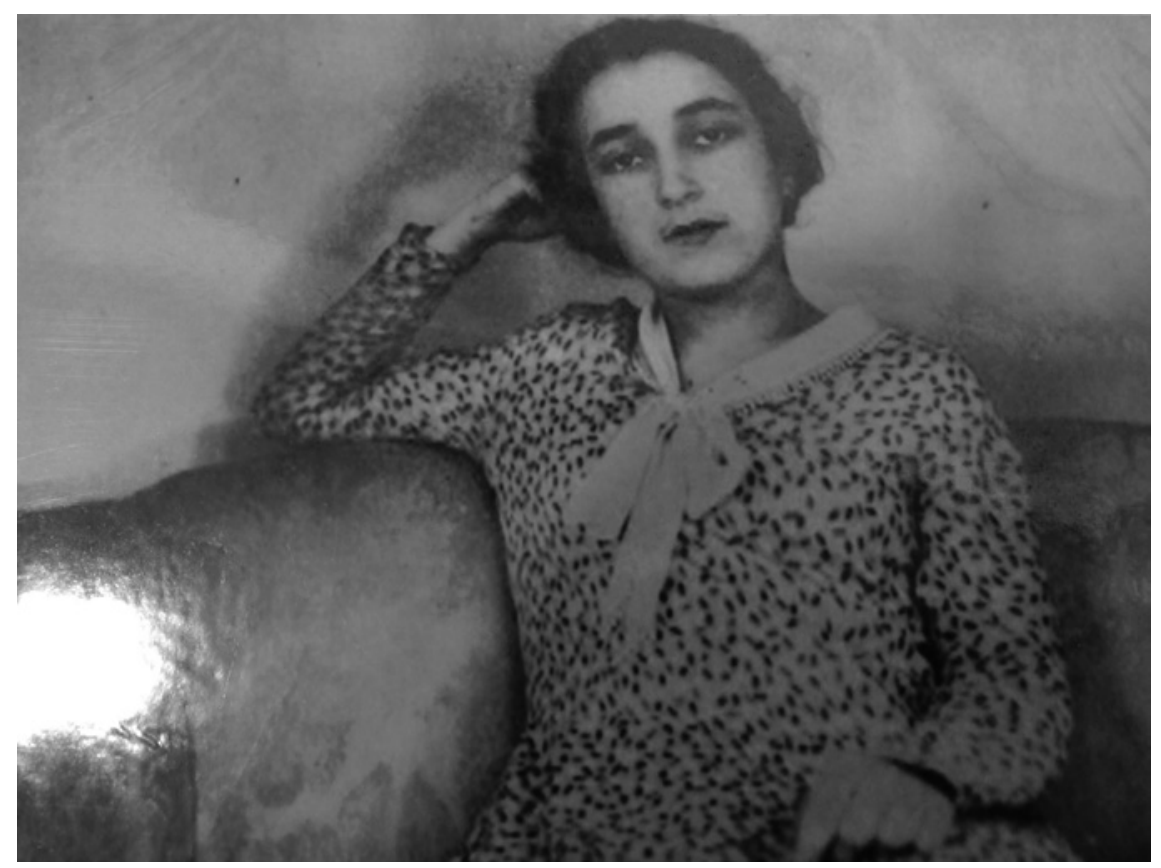

FIGURE 6.1 Luba Derczanska at the age of 21

doctors, engineers and lawyers all offered visions for a better future for mankind and they went to enormous lengths to shape that reality through institutions. The largest of these, the League of Nations, and its communist competitor, the Third International, were founded in 1919. By that time, international organizations of all kinds and directions had already been established. These included the Theosophical Society, the Woman's Christian Temperance Union, the Rotary Club, Boy Scouts groups, Zionist organizations, anti-slavery societies and central bureaux, which had been founded for everything a globalizing world could possibly need - international railways, educational facilities, stenography services, protection for indigenous peoples, defence of the natural environment, languages and cartographers. ${ }^{17}$ As Mark Mazower put it, 'the international had become the terrain upon which widely differing political groups and ideologies mapped their dreams and nightmares'.18

With large parts of the world still under colonial rule, the international organizations were by and large Western initiatives. Nonetheless, there were

17 League of Nations Search Engine (Lonsea Database, University of Basel), www.Lonsea.de.

18 Mark Mazower, Governing the World: The History of an Idea (London: Penguin Books, 2012) xiii. 
places outside the empire, Berlin for instance, where independence movements from the colonial world were welcomed, even encouraged. The Germans let them in, but Moscow provided the framework. In 1922, the Bolshevists moved the Third International to Berlin, turning the city into the organizational headquarters of world revolution. The Russian trade delegation served as its front and Willi Münzenberg, the orchestrator of Comintern activity, set up a string of bureaux for 'international literary propaganda', covering up for other activities. The Indian Bureau was one. ${ }^{19}$ It is important to remember though that it was not the only platform for colonial subjects in Berlin. Between the two world wars, the city also harboured Middle Eastern, Chinese and Japanese organizations, which were pursuing aims that ranged from communist and Islamic internationalism, to the founding of Chinese, Indian, African and Middle Eastern nation-states. ${ }^{20}$

When Luba Derczanska arrived in Berlin in 1925, she claimed to be a communist. Hamied remembers in his memoir that it was the first thing she told him. She said she was a member of the 'Polish-German-Russian Communist Party', and her first present to him was a portrait of Lenin. ${ }^{21}$ As required from communists when crossing borders, she will have applied for membership of the Comintern and regularly visited her local party cell, but in her letters she is silent about that. All she mentions are her visits to the Russian Association in the Russian embassy to listen to the lectures of Bolshevik grandees. ${ }^{22}$ The names of Georgi W. Checherin, the Soviet foreign minister, Maxim Litvinoff, the Soviet ambassador in London, and Anatoly Lunacharski, the first Bolshevik Soviet's people commissar are regularly recurring fixtures. ${ }^{23}$ Not only did Hamied call her 'a modern Russian woman', but her friends also much admired

19 Diplomats of the Foreign Office in Berlin made precise observations of the unfolding of the Third International in their city. AA PA Rußland Pol. 19, 'Bolschewismus, Kommunismus (3. Internationale) 1924-1930' (R 3.1707-3.1709).

20 Mitteilungen des deutschen Instituts für Ausländer an der Universität Berlin (1923-1942) (Communications from the German Institute for Foreigners at the University of Berlin). Chinese and Japanese students appear in rapidly growing numbers in the institute's published statistics.

21 K.A. Hamied, A Life to Remember: An Autobiography (Bombay: Lalvani Publishing House, 1972), 39-42.

22 As there is no entry for Luba Derczanska in the Comintern archive in Moscow, her application form, autobiography and recommendation letters will have been stored in the Comintern archive in Berlin and in 1933 transferred to the Soviet Union. A file could not be traced.

23 In her letters to Hamied she frequently mentions the 'Club' or 'Russischer Verband' (Russian Association). Hamied nicknamed it 'the Red Club'. Hamied private archive, DO201511-01 (Letters 1925-1927). 
her determination. Lucie Hecht, who worked for the bureau as a translator, wrote to her, 'I believe you will achieve much and I think Russia needs women like you'.24

For Russian speakers, Berlin had much to offer. After the revolution, 500,000 Russians descended on the city. Among them were Russian aristocrats, imperial officers and civil servants who had lost their homes and possessions overnight and had barely escaped with their lives. There were also Russian intellectuals and businessmen who refused to submit to the proletarian Bolsheviks. Most of these people left again as soon as the necessary transit visas had been obtained and ship passages booked, but some settled in the boroughs of Charlottenburg and Wilmersdorf. A Russian orthodox church was erected around the corner from the Ahmadiyya mosque in 1927.25

On a different footing, 40,00o Russian Jews regrouped in Berlin's poorest and most miserable neighbourhood, the so-called Scheunenviertel (barn quarter) behind Alexanderplatz. They had fled the warring zones of central Europe, lived through pogroms and massacres, and now made a living as pedlars and prostitutes. They called themselves Luftmenschen, people who survived on air. ${ }^{26}$ American aid societies and international Jewish relief organizations, in which German Jews participated, catered to their needs. For the German public at large, however, the poverty of the Ostjuden (Jews from the East) only confirmed their deeply ingrained prejudices. Soon after galloping inflation took hold, anti-Semitic sentiments culminated in the Scheunenviertel pogroms of $1922 / 3 \cdot{ }^{27}$

For the majority of German Jews, who had struggled for 100 years to leave poverty behind them and to become accepted as Germans, the large presence of Ostjuden in Berlin was embarrassing, ${ }^{28}$ not least because they spoke Yiddish, the jargon of the lower Jewish classes. While in central Europe, Yiddish was

24 Hamied private archive, DO2015-11-01-105

25 Karl Schlögel, Das russische Berlin: Ostbahnhof Europas (Munich: Pantheon, 2007). The church still stands today.

26 Anne-Christin Saß, Berliner Luftmenschen: Osteuropäisch-jüdische Migranten in der Weimarer Republik (Göttingen: Wallstein Verlag, 2012).

27 Jochen Oltmer, 'Prekäre Duldung und aktive Intoleranz: Das Schicksal jüdischer Flüchtlinge in der Weimarer Republik', in Stiftung Jüdisches Museum Berlin (ed.) Berlin Transit, Jüdische Migranten aus Osteuropa in den 192oer Jahren (Göttingen: Wallstein Verlag, 2012), 34-7; Anne-Christin Saß, 'Scheunenviertel', in Dan Diner (ed.) Enzyklopädie jüdischer Geschichte und Kultur, vol. 5 (Stuttgart: Metzler, 2014), 352-8.

28 Gennady Estraikh and Mikhail Krutikov (eds) Yiddish in Weimar Berlin: At the Crossroads of Diaspora Politics and Culture (London: Modern Humanities Research, 2010); Stiftung Jüdisches Museum Berlin, Berlin Transit:Jüdische Migranten aus Osteuropa in den 1920er Jahren (Göttingen: Wallstein Verlag, 2012). 
being rediscovered as a literary language and quickly became the beacon of the emancipated young, to German ears it sounded like corrupt German, a mockery of their language with which the German Jewish middle classes did not wish to become associated. ${ }^{29}$ Nonetheless, in Vilna, Kaunas, Kiev and Odessa, vibrant avant-garde Jewish circles thrived and after the Jewish refugees arrived in Berlin the Yiddish press boomed. Yiddish writers and exponents of Yiddish culture regrouped in the literary cafés on Kurfürstendamm, notably Café des Westens and Romanisches Café, where they sat at their own tables and discussed the revolution. ${ }^{30}$

There is no indication in her letters that Luba Derczanska sought out the company of any of those Russians. She did not mingle with the Russian bourgeoisie (with whom she had nothing in common). She did not engage with the Jewish poor (although her friend Gerda Philipsborn, an opera singer, spent her days helping the orphans). Neither did she visit the places where Yiddish writers met (although she must have known a good many of them). Far from the noisy migrant hubs, she settled in the quietest corner of conventional Jewish Berlin, between Tiergarten and Moabit, on a bend of the river Spree.

\section{The Jewish Network}

The envelopes scattered between the letters show that Liubov Derzcanska was now, for the sake of simplicity, calling herself Luba. They also tell us that between March 1925, when she arrived, and December 1929, when she went to Bombay, she moved house nine times. Her first lodgings were in a corner house overlooking the river Spree at Levetzow Strasse 15; then followed a string of sublet rooms around the corner, in which she either had a direct view of the river, or lived in a side street one house removed from it. ${ }^{31}$ Apart from the embankment, which was where the big houses were, five smallish streets filled

29 Like Dutch and Danish, Yiddish is a Germanic language that developed from the High German from the fourteenth century onwards, incorporating Hebrew, Russian and Polish words and expressions while progressing. Harald Haarmann, Weltgeschichte der Sprachen: Von der Frühzeit des Menschen bis zur Gegenwart (Munich: CH Beck, 2006), 188; Uriel Weinreich, College Yiddish: An Introduction to the Yiddish Language and to Jewish Life and Culture (New York: YIVO, 1992), 54-6o.

30 Estraikh, Yiddish in Weimar Berlin; Karl Schlögel and Karl-Konrad Tschäpe, Die russische Revolution und das Schicksal der russischen Juden: Eine Debatte in Berlin 1922/23 (Berlin: Matthes \& Seitz, 2014).

$31 \quad$ Among these were Altonaer Strasse 12, Thile-Wardenberg Strasse 12, Wullenweberstrasse 3, and Levetzowstrasse 12. 
with comfortable apartment buildings criss-crossed the bend, and there was a large synagogue on the corner between Jagowstrasse and Levetzowstrasse. Of liberal persuasion, it could accommodate 2000 visitors and attached to it was a community centre, a religious school and a smattering of community apartments. ${ }^{32}$ The names of her landlords - Levin, Bronstein, Rosenthal, Jacob, Kußman, Liebman, Fleischner and Finkel - suggest that Luba settled well into this community, moving from one Jewish family to the next. Because the river bend was heavily bombed during the Second World War, many of those houses no longer exist, but from the towpath overlooking the tree-lined Spree, one gets an idea of the tranquil cosiness it must once have offered.

How is it possible that a young Jewish woman fresh from central Europe, whose voice and manner marked her as Ostjude, could be welcomed in this particular setting? ${ }^{33}$ Not too far from where she lived and a brisk walk of approximately twenty minutes through Tiergarten and Schöneberg, her aunt lived in an eight-roomed apartment block behind Bayerischer Platz, a newly built neighbourhood into which well-to-do Jewish people had settled. Pauline's sister Bertha had married a German officer, who had been a pilot during the First World War and afterwards acquired a position in the higher echelons of the civil service. ${ }^{34}$ The large black car in the film sequence had been his. Bertha was wealthy and felt at ease in the German Jewish milieu. In marrying Arthur Tänzler, she had embarked on a mixed marriage that broadened her horizons. Around 1900, this was still an unusual thing for eastern European Jews to do, but in German Jewish circles it was increasingly recognized as an acceptable entry into German society. By 1910, 10 per cent of the Jewish population had entered such marriages. ${ }^{35}$

In the Derczanska family, in which the conventional and the revolutionary constantly rubbed shoulders, leaving the Jewish fold had been practised before, but that did not mean that the rest of the family had approved. When Pauline's sister left for Berlin to marry into upper-class German society, Rubin's

32 Carolin Hilker-Siebenhaar, Wegweiser durch das jüdische Berlin (Berlin: Nicolai, 1987), 134-6. The synagogue was damaged during the war and demolished in 1955 .

33 Shuster remarked on her Yiddishkeit. A recording of her voice has been preserved in 'A Rose called Zakir Hussain' (Bombay: Film Division, n.d.)

34 In the Berliner address book of 1936, there is the entry of 'Arthur Tänzler, Landesoberinspektor und Bertha Tänzler, née Joffe. Berlin W30, Freisingerstrasse 5a. Phone: B 6 Cornelius 2415'.

35 Todd M. Endelman, Leaving the Jewish Fold: Conversion and Radical Assimilation in Modern Jewish History (Princeton: Princeton University Press, 2015), 147 ff.; Kerstin Meyring, Die christlich-jüdische Mischehe in Deutschland 1840-1933 (Hamburg: Dölling und Galitz Verlag, 1998), 94-5. In 1910, ten per cent of German Jews were in mixed marriages. 
sister Revekka went to Kharkov in Russia, where she wholeheartedly supported the communist endeavour. From her letters, we know that she was a simple woman - her imperfect Russian-Yiddish and Yiddish-Russian indicate that who chose a Russian menial worker as a partner and had at least one daughter with him. ${ }^{36}$ Her relationship with Rubin was stormy, as was Bertha's with her sister Pauline. Nonetheless, when all was said and done, what counted was the family bond. When her parents arranged for Luba to study in Berlin to become a teacher of religion, it was on the strength of Aunt Bertha already living in that city. When she moved from Kaunas to Berlin, it was only natural for her to ask Aunt Bertha for help.

Luba was more conservative than her aunts. Once in Berlin, she moved in and out of a number of overlapping Jewish circles. Not only were all her landladies Jewish, so too were the doctors she saw - Dr Liebman, Dr Karl Meyer and Dr Weinberg, whom Hamied would later help to flee from Nazi Germany (Chapter 7 ). The few German women with whom she engaged - Gerda Philipsborn and Lucie Hecht - were also Jewish. She met them in the offices of the Indian Bureau, where they equally supported the Indian revolutionary cause. Gerda Philipsborn belonged to an old, wealthy family in which each new generation embraced different means of changing the world. Her sister Claire ('Clarita') was in the Spanish Civil War. ${ }^{37}$ Her sister-in-law Regina was a composer and conducted an orchestra of contemporary music. ${ }^{38}$ Gerda was not afraid to dirty her hands. As a bemused Muhammad Mujeeb noted, 'she worked for a refugee camp for Jewish children in Berlin and went to good lengths collecting funds, furniture and other things for them. Often enough she would be seen in the streets of Berlin carrying things on her person for them, very much like an ordinary labourer.' ${ }^{39}$ When Mujeeb made this observation, Gerda had already taken it upon herself to introduce his friend Zakir Husain to German high culture - music, literature, philosophy, the cultured German home. It was Zakir, however, who had previously initiated the contact between the pair by introducing Gerda to the Indian cause (Chapter 7 ) ${ }^{40}$

36 Hamied private archive, DO2015-11-05-(92, 96, 98). Both the Russian and the Yiddish translator remarked upon her style of writing. The name of the daughter was Ida. Judith Berlowitz and Camarada Clara, The ( fictional) diary of Clara Philipsborn (Oakland, CA: Self-Publishing, 2018).

38 Judith Berlowitz, From the Family Store to the House of Lords: The Jewish Family Philipsborn of Bentschen and their Descendants (Oakland, CA: Self-Publishing, 2016), 539-44, 564-5.

39 Gene Dannen, 'A physicist's lost love: Leo Szilard and Gerda Philipsborn'. www.dannen .com/lostlove. 26 January 2015; M. Mujeeb, Dr Zakir Husain: A Quest for Excellence (New Delhi: National Book Trust, 1972), 36-9. 
As we saw in Chapter 2, Lucie Hecht came to the Indian Bureau via a different route. She had been living comfortably with her parents in PotsdamBabelsberg and studying at Berlin University until, after the crash of 1923, she was forced to look for a job. By accident, she found one with the Indians in Halensee. Lucie was an intense woman and the Indians did not always understand her, as we saw from the rather unflattering portrait that Muhamed Mujeeb, a regular visitor, painted of her and which is discussed in Chapter $2 .{ }^{41}$ Nonetheless, however she was received, she was passionate about the Indian cause and was happy to translate whatever her boss thought important: these works included Zakir Husain's thesis, articles by the American communist Agnes Smedley, the poetry of Tagore, and the notes of the Congress against Colonial Oppression and Imperialism that was held in Brussels in 1927 (Chapter 7). ${ }^{42}$ In 1932, when the political climate forced communists and their sympathizers to leave Germany, the bureau's leader Chattopadhyaya went to Moscow to promote the Indian connection. Gerda Philipsborn followed Zakir Husain to India to help build a national university, the Jamia Millia Islamia, and the bureau collapsed.

Lucie Hecht lingered on for some time in Berlin translating for British and American reporters and, with their support, eventually made her escape to London in 1939. While barely surviving at first, a stroke of luck brought her into contact with the Zionist offices in Great Russell Street and she became the executive secretary of and translator for the Women's International Zionist Organization. She settled down, acquired British citizenship and would have stayed in London for the rest of her life had it not been for her parents and sister, who were groping for a foothold in Germany after the war and badly needing her support. ${ }^{43}$ Her contact with Luba Derczanska seems to have been severed.

Luba's best friends were not German. They were, like her, Russian Jews with Polish passports. Hamied mentions them in his memoir - Sonia, Dunia and Estusia. Her letters tell us that Estusia (Esther) Tenenbaum was born in Warsaw,

41 Mujeeb, Dr Zakir Husain, 38.

42 Lucie Hecht received fleeting mention in a number of biographies, see Nirode K. Barooah, Chatto: The Life and Times of an Indian Anti-Imperialist in Europe (Oxford: Oxford University Press, 2004) 214, 224; Margarete Buber-Neumann, Von Potsdam nach Moskau: Stationen eines Irrwegs (Cologne: Edition Maschke, 1981), 93-106; Babette Gross, Willy Münzenberg, eine politische Biographie (Frankfurt am Main: Büchergilde Gutenberg, 1967), 197ff.; Mujeeb, Dr Zakir Husain, 38; Ruth Price, The Lives of Agnes Smedley (Oxford: Oxford University Press, 2005), 155, 451.

43 In a long letter to Surasini Chatto, dated 10 March 1967, Lucie Hecht recounts what happened to her and her parents during the Nazi persecution. Private Collection Lucie Hecht, Horst Krüger Papers, Box 33, 240-1. 
while the sisters Sonia and Dunia P/Frada hailed from Vilna. ${ }^{44}$ It is tempting to think that they left that town together, and that Sonia and Dunia were the other two Vilnerkes that Shuster captured in his sketch. However, irrespective of whether their friendship went back a long way or began in Berlin, it was with these three women that Luba shared her evenings, the Russian language and a Jewish network that eventually stretched between Vilna, Berlin, Moscow and Bombay. Like her, they were Jewish and loyal communists, and they all studied in the physics department because they were convinced that the future belonged to the natural sciences. The four of them constituted an inner circle, in which their fiancés - Hamied for Luba, and Arthur and Nizamuddin for Estusia were allowed to participate. ${ }^{45}$ Judging from their frequent appearances in the group photographs of Indians in Berlin (Chapter 2), they clearly supported the Indian cause.

Descriptions of how the friends communicated are scattered throughout the letter archive. In 1927, when Hamied went to visit his parents in Aligarh, Luba adopted the habit of describing her daily routines to him. Whether her visits to the Russian Association ('the second night I was there with Sonia and Dunia'), her observations of the Indian winter festival ('there were very many Russians there'), or their nightly gatherings ('Estusia and Arthur are our best and most intimate friends'), her friends were always in the vicinity. When Luba left for Vilna, she described how they all came to the station to say goodbye to her. 'Estusia and Nizam helped me with the luggage. Dunia, Sonia, Azluk and Auntie were in the waiting room. In Warsaw, Dunia's sister came to the station.' 46 It was a tightly knit circle that knew each other well. Estusia wrote trustingly to Hamied, asking him to send her some frogs, 'if possible the kind that is common in India, those small ones. You can put them in a jar with alcohol and put the jar in straw in a box. ${ }^{47}$

In the same envelope there was also a letter to Hamied from Estusia's fiancé Arthur, which throws light on the position of the men in the circle. He writes:

I have to thank Stusia for her kindness in letting me read all your letters. ... I have already spoken to Luba and Stusia about this, that I cannot forgive myself for having been so foolish in the past. Out of shame and for other

44 Envelopes and scattered remarks across DO2015-11-03.

45 Arthur K. ('Artiuk', 'Azluk') was a student by profession. He frequently paid visits to Estusia Tenenbaum at Gervinusstrasse 4 in Berlin-Charlottenburg. His German was polished although slightly faulty. His parents lived in Berlin and he even introduced Luba to them. It is not known whether they were Jewish.

46 Hamied private archive, DO2015-11-02-06.

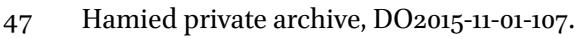


petty reasons, I only met you occasionally. We should rectify that. ... When we discussed things with you at Stusia's place, I was often not very tactful. Please forgive me, I beg you $4^{48}$

After having apologized for his earlier behaviour - he had avoided meeting him and whenever they did meet had been rude to Hamied - Arthur continues to address the topic that was on their minds, namely that Hamied was not a communist, let alone a member of the Communist Party: 'so that is how we spend whole nights discussing ... how we can convert you - Hamied - to our nationality. May Allah rescue you from the thought that I am making jokes. I am bloody serious about this metamorphosis problem.49

Although Luba's friends clearly liked Hamied and their letters are full of endearments towards him, it was a real problem for them that he, unlike them, was not dedicated to the Soviet cause. Hamied was a nationalist, somebody who believed in the future of the Indian nation-state and, in the past, Arthur seemed to have bullied him about it. It must have caused tensions in the group, for, after all, Luba loved Hamied. Arthur's attempt to apologize and to voice his concerns to Hamied in writing, had previously been discussed with Luba and Estusia. That much he admits. Maybe they had put pressure on him to write that letter. That it was not easy for him to do so is apparent from his clumsy salutation: Mahlzeit Kollege! ('May it go down well Comrade!'). That was German communist parlance, and very proletarian.

The letters, however, are remarkably taciturn about their lives as RussianPolish communists in Berlin, revealing little about how they lived, and from what. Much later, in 1935, when they were already scattered across the world Luba in Bombay, Sonia, Dunia and Azluk in Moscow, and Estusia in Tel Aviv the latter wrote a long, troubled letter to Luba, in which she defended her decision to have gone to Palestine instead of Russia. What becomes evident from her words is that, for the inner circle, being a communist was a choice for life, and not something one could easily discard. It was aggravating that, for Jewish communists who believed in Russia's future, the choice vehemently excluded Zionism. ${ }^{50}$ Estusia must have been in dire straights to side secretly with the

48 Hamied private archive, DO2015-11-01-107.

49 Hamied private archive, DO2015-11-01-107.

5o Mark Mazover paints a lively picture of how deep such feelings ran. Himself from a family of dedicated Vilna communists, he remembers how, at the end of the twentieth century, the question of Zionism still managed to upset his parents' dinner table. Mark Mazower, What You Did Not Tell: A Russian Past and the Journey Home (London: Penguin Random House, 2017), 249. 
Zionists. ${ }^{51}$ To Luba she describes how the friends reproached her for not being in Moscow with them, how Arthur put pressure on her, accused her of desertion and complained that he was lonely and could not wait for her any longer. She wrote to her about the nightly telephone calls between Moscow and Berlin, the tears, and how her parents in Tel Aviv pleaded with her not to go to Moscow. Finally, she said, she made up her mind, but leaving Berlin in the direction of Tel Aviv made her feel so guilty that even saying goodbye to Auntie Bertha had not been an option, so much did she dread the inevitable questions: 'I do not want to make excuses, because there is no excuse for me. I will tell you the main reason for my silence, it was, I will say it openly, my cowardice. I was ashamed to write to you that I was going home.52

Estusia's letter to Luba lays bare several things. Written three months after she reached Palestine, it describes her struggle over her communist and Zionist loyalties. What it does not mention is that this struggle was taking place in the midst of Nazi Berlin and that the political situation there strongly informed Estusia's decision. The Nazis were stepping up their discrimination against Jews in preparation for the Nuremberg Laws, and Estusia had felt its impact. After writing a brilliant dissertation at Berlin University, she was appointed as a research assistant in the genetics department of the famous Kaiser Wilhelm Institute (KWI) for brain research in Berlin Buch. However, when the Nazis ordered the KWI to dismiss foreigners, Jews and women - the majority of the work force - her career was threatened. A grant from the Rockefeller Foundation helped her to stay on for another year, but in 1934 she faced forced emigration. ${ }^{53}$

Nowhere are those conditions mentioned. Instead, Estusia's account centres on a long dissolved circle of friends but one that still managed to influence her thinking. For Azluk, Dunia and Sonia - a chorus backed by Luba's sister Fania, who had also settled in Moscow - it was essential that Estusia join them and they were wondering what was taking her so long. During their nightly telephone calls Estusia will have glossed over the Tel Aviv option simply because she felt ashamed of even considering the possibility. In her own mind, she had not been forced out of Germany. She had committed treason and therefore did not dare to write.

$5^{1} \quad$ In a letter to her mentor Oskar Vogt, dated 1933, she had already confessed that she was a Zionist, C. and O. Vogt Archive, Duesseldorf. With thanks to Annette Vogt for drawing my attention to their correspondence.

$5^{2}$ Hamied private archive, DO2015-11-05-05. Translation from the Russian by Botakoz Kassymbekova.

53 Anette B. Vogt, 'Estera Tenenbaum 1904-1963', Jewish Women's Archive. https://jwa.org/ encyclopedia. 
The letter leaves a question mark over the kind of link that tied the friends together. Was their circle a communist cell, a unit with a special mission in the sprawling Comintern network in Berlin? Margarete Buber-Neumann, a young German communist who for some time also worked for the Indian Bureau, offers an insightful observation into how foreign communists organized themselves in Berlin:

To communist immigrants who did not want to betray their conviction, it was forbidden to assimilate or even to become a member of the Communist Party of their host country. Security reasons forbade that. In their majority they became professional revolutionaries ..., working for one of the numerous camouflaged Comintern enterprises in Germany. ${ }^{54}$

Buber-Neumann's observation raises the question of how Luba and her friends made a living. Their frequent appearance in Indian Bureau group photographs (Chapter 2) seems to indicate that, after Luba met Hamied, they became involved in the Comintern organization, but the details largely elude us. The letters show that Luba herself cooperated with Lucie Hecht in some unnamed tasks about which she spoke to Hamied on several occasions, ${ }^{55}$ but did they also provide her with an income? All one can conclude is that her financial status was precarious. Soon after they met, Hamied took her into his financial care. His concern for her speaks from his every letter: 'take the eggs from my fridge. ... You can take as much money as you need from the bank. Everything that is mine is yours. ${ }^{56}$ He paid for her tuition fees and for her doctor, and gave her money whenever he could. Even while he was in Aligarh and she in Vilna, he kept sending cheques to Estusia, which he would ask her to cash and then send the money on to Luba in an envelope, so that she would have no need. Financially, now she was free to devote herself to her studies.

What makes Esther Tenenbaum (1904-1963) stand out from her friends is her distinguished scientific career. She sparkled as a student in Berlin and continued to shine after she migrated to Palestine. In 1936, she found work at the Hebrew University, first as a laboratory assistant and then as a junior assistant until she acquired a lectureship in experimental pathology. Some time after that she joined the Department of Experimental Medicine and Cancer Research from where she worked as a guest scholar in Paris, Cambridge, London and Edinburgh. Finally, she travelled to the United States and worked for a

54 Buber-Neumann, Von Potsdam nach Moskau, 104.

55 Hamied private archive, DO2105-11-01-(72, 93).

56 Hamied private archive, DO2015-11-01-49. 
while at the California Institute of Technology in Pasadena, where she carried out experiments on brain tissues in vitro. ${ }^{57}$

After a series of affairs with different men in Berlin (see below), she remained unmarried for the rest of her life, but in Tel Aviv entered a relationship with the painter Miron Sima (1902-1999). The couple had much in common. Like her, Sima was a Russian refugee who had found a new home in Germany. Whereas she studied in Berlin, he enrolled in the art academy in Dresden where his exceptional talent was quickly recognized. Like she had been, he too was forced out of Germany. However, for the rest of their life together the couple conversed in German, sharing memories of their life in Germany, and feeling homesick. When she died in Tel Aviv in 1963, Sima seems to have taken care of her possessions, of which only some photographs remain. ${ }^{58}$

Estusia's letter to Luba finally manages to throw some light on Luba's position in the network. In the opening sentence, Estusia expresses her astonishment by saying that 'I did not expect a letter from you'. In fact, on the contrary, she had expected Luba to side with the others, especially with her sister Fania who seemed to gain an authoritative voice in the circle once it settled in Moscow. Nonetheless, she knows she can trust her:

Liubochka, I wrote openly about everything because I know I can write this to my best friend. But I ask and beg you not to write about this, not even to Fania. ... Unfortunately, here at home and everywhere around here, people hate Fania's friends and my parents think I would perish there with them. ${ }^{59}$

In 1934, Esther Tenenbaum made up her mind. To all appearances, Luba Derczanska had made up hers too when she decided to marry Hamied and follow him to India. Remarkably, she managed to keep in touch with her friends, both in Berlin and after their departure to Moscow. Although none of the letters that reached her during the crisis following Estusia's desertion survived, Estusia's words amply show that they all trusted her. Letters written in Moscow must have informed her of what was going on. Somebody also sent her the Tel Aviv address. Then she sat down and wrote a letter that managed to bridge the gap once more. Luba was a go-between, a person who was able to keep the balance

57 Vogt, Estera Tenenbaum.

58 Private estate of Miron Sima in the Mishkan Museum of Ein Harod, Israel. With thanks to Noah Benninga (Hebrew University in Jerusalem) for following Esther Tenenbaum's trail.

59 'Liubochka' is a Russian diminutive that only intimate friends are entitled to use. Here, it is used as an invocation. Hamied private archive, DO2015-11-05-05, translation from the Russian by Botakoz Kassymbekova. 
between extremes and bridge differences. In her life with Hamied in Bombay, that quality would still come in useful. However, at the start of their relationship, she employed it to monitor the Indian-Jewish connection. In the process, not only their lives, but also their respective personal networks became dovetailed. In the following section, I recount how that was realized.

\section{$4 \quad$ Micro Strategies of Globalization}

Khwaja Abdul Hamied entered Luba's world on 18 April 1925. It was a pure coincidence. His professor had invited him to join a student outing on the lakes around Berlin and she happened to be on the same boat with another group. He performed some card tricks and, looking over his shoulder, she managed to see through his illusion. They started a conversation and, from that, their relationship was born. ${ }^{60}$

Originally, Hamied had come to Berlin with a group of friends whom he had met in the Non-Cooperation Movement at Aligarh University, the full story of which will be related in the next chapter. Like Zakir Husain, Muhamed Mujeeb and Abid Hussain, he was making plans for the future of India and engaged simultaneously in writing a dissertation and meeting Indian politicians. He envisioned his own future in the field of chemistry, the basics of which he planned to introduce to his country. The four of them were regular visitors to the Indian Bureau and, as a matter of course, knew about its communist associations. Later in life he would often recall how he and his friends defended the abolition of violence. While most of the workers in the Indian Bureau did not shy away from the thought of a violent revolution, Hamied and his friends tried to convince them otherwise. That was his position when he and Luba met.

His first letter, the very first in Luba's letter archive, was written four days after they met and, since she had written to him first, it was in response to hers. ${ }^{61}$ Their initial encounter had clearly affected Hamied. In his letter, he described how the next day he had felt feverish and unwell, and had consulted a doctor about the possibility of x-ray radiation. He also told her that he could not forget her beautiful eyes and asked if he could please see her again. She was more cautious. Although she gave him a photograph of herself, she decided that he could visit her only once a week, but should write to her about himself on the other days. A month later, he moved to Kirchstrasse 13, which was in her neighbourhood, a mere ten minutes' walk along the towpath. Between their

6o Hamied, A Life to Remember, 40-1.

61 Hamied private archive, DO2015-11-01-(01-03). 
respective rooms there was also a much faster shortcut through Tiergarten. After that move, she stopped writing for a while. ${ }^{62}$

In the summer following their meeting, Luba left Berlin for a prolonged walking tour in the Harz mountains of Germany. Hamied was not allowed to come. The village in which she lodged, and where she received his letters, was called Elend, which is also German for miserable. Henceforth, that is how he described himself, and that is how she addressed him: Elender Hamied! (miserable Hamied!). ${ }^{63}$ It was their first private joke. The language in which they communicated was German, which she mastered better than he did because of her grasp of Yiddish and her linguistic education. He too managed well; he copied lines from Goethe and from the books she lent him, and took on the difficult German grammar without inhibition, conjugational pitfalls notwithstanding. German was the language in which they settled down together, albeit creating their own version of it as they went along. In fact, for the rest of their lives they would use it in their private communications. It was only during the war, when the Germans attacked central Europe and Luba's anxiety was mounting by the day, that he fell back on English in an attempt to alleviate her anxiety.

For the next two years they lived in a cocoon; it was as if they were in incubation. As students, their life together took place between classroom obligations, exams, political events, and meeting up with friends. Luba studied hard to become a laboratory assistant. Hamied acquired his doctorate and launched into a series of internships in German chemical plants. Whenever he was in Berlin, she would expose him to her communist outlook and to the Soviet embassy, while he would introduce her to his friends from Aligarh and to the Indian Bureau. A photograph of an Eid al-Fitr celebration in Hamied's rooms bears witness to the fact that he also introduced her to the festive spirit of Muslim celebrations. ${ }^{64}$ Through his attempts to link Muslim and Hindu Indians, Hamied was used to introducing people to one another who were of different persuasions. Adding a Jewish communist from central Europe fitted in well with that.

After Zakir Husain and Abid Hussain returned to India in 1926, Hamied's most important friends in Berlin were Ishaq Shahidi and Nizamuddin Ahmad. Like Hamied, they studied an abstract field of science and, like him, they courted European women. Shahidi fell in love with Hilde Rahel Scharf and, in their letters to each other, Luba and Hamied repeatedly discussed their relationship.

62 Hamied private archive, DO2015-11-01-(02, 38).

63 Hamied private archive, DO2015-11-01-(04-71).

64 Hamied private archive, Berlin Album, 22. 
Shahidi originated from Lahore, where his family had probably been involved in the Ahmadiyya movement. In Berlin, he regularly participated in Ahmadiyya community life. Hilde wrote a conversion narrative in which she describes how they met. Apparently, she first saw Shahidi when she was teaching German to foreigners at Berlin University. They spoke about religion together, and he introduced her to the mosque's lectures and festivals. One day she decided to participate in the prayer as well and that experience accelerated her decision to embrace Islam. ${ }^{65}$ They married in 1927.

For some years, Nizamuddin courted Esther Tenenbaum and, whenever the couples were together, he always seemed close to Estusia. In the letters, they are also often mentioned as a pair. In the photographs, we see them repeatedly holding hands. In the end, the courtship failed, although they seem to have continued intermittently. A photograph taken at a New Year dance in 1926 shows them all still together. Hamied, Shahidi, Luba and Nizam are standing. Sonia (or Dunia), Hilde and Estusia are sitting. Shahidi has his hands on Hilde's shoulder and Nizam and Estusia are holding hands. Lucie Hecht is the woman sitting at an angle (Figure 6.2). ${ }^{66}$

Luba's was not the only inner circle to experience an enlargement, for her Jewish network on the Spree also benefited from her relationship with Hamied. At first, she introduced Hamied to her doctors and her various landladies. In the letter archive there is a postcard from Mrs Jacob to Hamied in Aligarh, on which half the neighbourhood have scribbled their greetings ${ }^{67}$ and her daughters appear in some of the Indian Bureau photographs (Chapter 2). Mrs Jacob's portrait was later allotted a place in Hamied's Berlin photograph album, ${ }^{68}$ and the Liepmans and Rosenthals seem to have enjoyed a similar kind of relationship with him. ${ }^{69}$

Shahidi also moved into the neighbourhood and, judging from the envelopes, he and Hilde lodged with the same group of landladies. For the longest time they lived with the Jacobs at Flensburgerstrasse, a homely street just across the river from where Luba was staying. It is no coincidence that the Urdu Association, of which all the Muslim Indians in Berlin were members

65 Hildegard Scharf, Irma Gohl and Huda J. Schneider, 'Drei Europäerinnen bekennen sich zum Islam', Moslemische Revue, 1 (1931), 53-9. Her photograph was printed on p. 32.

66 Hamied, A Life to Remember, 48-9. Comparing this with other photographs made identification possible, see Chapter 2.

67 Hamied private archive, DO2015-11-01-102, eight different handwritings.

68 Hamied private archive, Berlin Album, 26.

69 Hamied private archive, DO2015-11-01-97, DO2015-11-02-04, et passim. Once Hamied departed for India, the Liepmans and Rosenthals repeatedly sent him the latest news. In her own letters, Luba noted with how much esteem they spoke of him. 


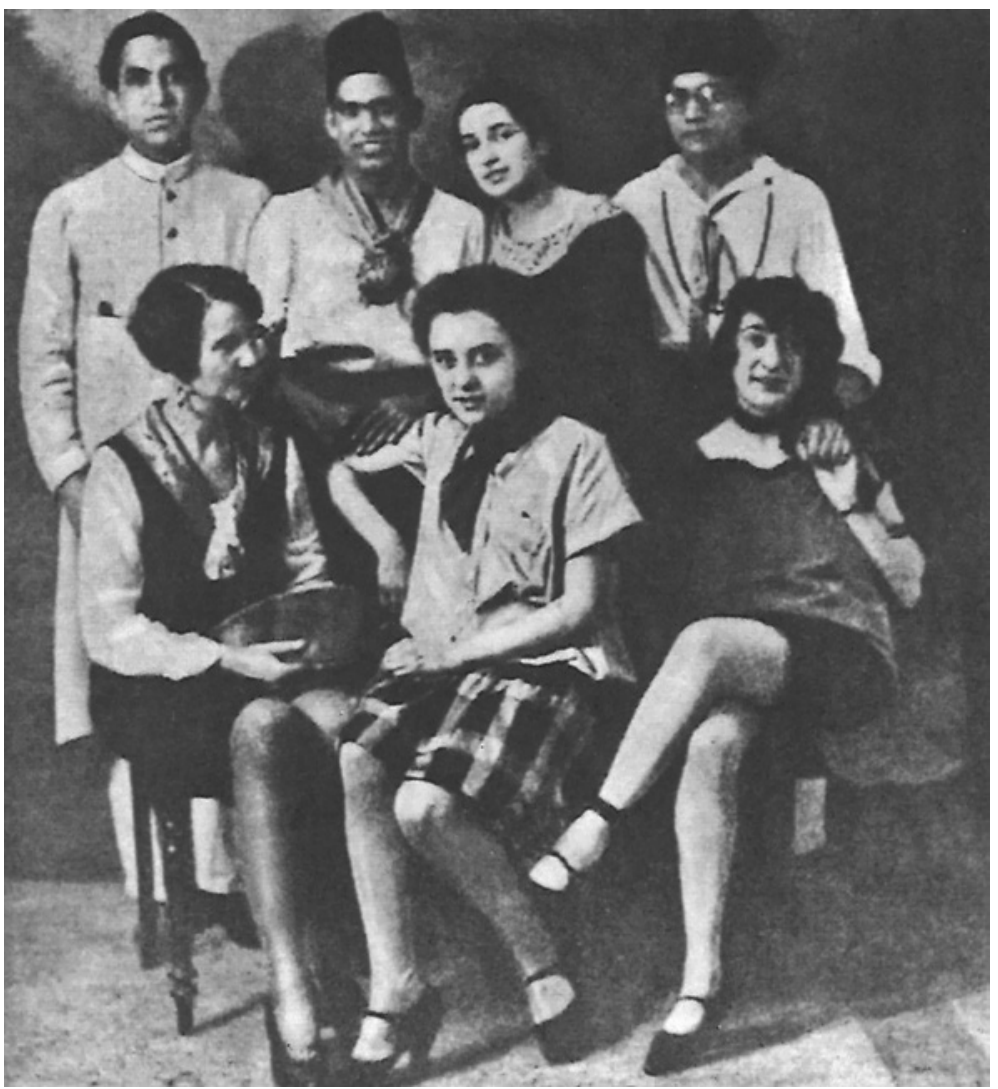

FIGURE 6.2 The Red Club, 1926

and to which Luba and her friends were regularly invited, set up headquarters at the Café Köhler, which was neatly situated on the riverbank between their respective places. ${ }^{70}$ Aunt Bertha in Schöneberg participated in the growing Indian-Jewish network as a matter of course, inviting the friends to coffee and cake at her home, and sharing in the farewell scenes at the railway station.

Globalization has been defined as the worldwide interlinking of transport, commerce, politics, languages, cultures, and people. ${ }^{71}$ From that vantage point, what took place in that little corner of Berlin was globalization at close quarters. To return to Linda Colley, whom we encountered in the Introduction, this micro strategy adopted by people who happened to live together in fact marked

$70 \quad$ Hamied private archive, Do2015-11-01-(34, 50).

71 Jürgen Osterhammel and Niels P. Petersson, Geschichte der Globalisierung: Dimensionen, Prozesse, Epochen (Munich: Beck, 2012). 
a momentous period when global history became compressed. ${ }^{72}$ Previously, Jews in Europe and Muslims in India had certainly heard of one another. They had sampled each other's manufactured goods, maybe even tasted each other's produce, but back in the 1920 s, they had never actually met. When that happened, or so the interactions on the Spree embankment seem to tell us, they were curious about one another and remarkably trusting. When Hamied travelled to India, Estusia asked him to send her frogs. Despite his qualms, Arthur could not restrain himself from asking Hamied to describe the jungle and the Maharajas. Mrs Jacob expressed what everybody felt when she wrote that she hoped he'd be back in no time at all. ${ }^{73}$

That the participants in this little network were either Jewish or Muslim was something that was rarely commented on. Maybe it hardly played a role. As I explained in the Introduction, the Muslims in the group were raised as modernists, searching for ways to harmonize traditional with Western knowledge. All Jewish women came from families that in some way or another had grappled with Haskalah, the Jewish Enlightenment and afterwards tolerated secular, even atheistic forms of Jewishness. It may be assumed that the participants in the network looked for societal consensus rather than cultural difference. Certainly, they did not spell out theological differences. What the couples and their landladies shared was a secular, middle-class upbringing and, through that, expectations of how to present themselves and to communicate with the other. That seemed to be a stable enough basis upon which to build.

When Magnus Hirschfeld, the famous Berlin professor in sexology and himself a Jew, lectured in Bombay in January 1932, the Hamieds threw a party for him. ${ }^{74}$ Hirschfeld was fascinated by their 'mixed' marriage and mused in his diary that marriages between Muslims and Jews seemed unexceptional. Asking the couple how that could be possible, Luba offered him what he called an 'indicative answer': she said it was 'because Muslims are three-quarters Jews anyway. ${ }^{\prime}$ Her response will have mirrored a standing joke, maybe their answer to the Nazi obsession with half, quarter and one-eighth Jews. Nonetheless, it managed to capture the innocence with which participants in the Muslim-Jewish network in Berlin had once behaved.

Within Luba's personal circle, three Muslim-Jewish relationships were established. In due course, one couple broke up, and the other two decided to

72 Linda Colley, The Ordeal of Elisabeth Marsh: A Woman in World History (New York: Random Books, 2007), 300.

73 Hamied private archive, DO2015-11-01-102.

74 Hamied, A Life to Remember, 109.

75 Magnus Hirschfeld, Weltreise eines Sexualforschers im Jahre 1931/32 (Frankfurt am Main: Eichborn Verlag, 2006), 320. 
marry under Muslim law in the Berlin mosque. That decision, although a guarantee for decency when moving in with each other, also indicated problems ahead. What became a recurring topic in the letters was the question of how to tell their parents, and when.

In October 1927, Hamied's time in Berlin was drawing to an end. He had finished his studies, completed a number of internships, and his money was running out. His parents were expecting his imminent return. The lovers were apprehensive. The decision to marry had been postponed until they had each spoken with their respective parents. When Hamied finally booked a ship's passage to Bombay, it was with that in mind. Nonetheless, India was far away and it was unclear how they would continue in the future. Would they ever see each other again? Their farewell reflected that uncertainty. ${ }^{76}$

Before he left, they came up with a new plan. While he was at home seeking an opportunity to speak to his mother, Luba would go to Vilna to do the same. That way, they would be able to describe to each other how things were proceeding. On 15 November, Luba was able to tell Hamied that Sonia had already secured her the certification she required to apply for a job in a Vilna office and, apparently, a precondition for her travel. On 1 December, she disembarked from the Berlin-Warsaw-Vilna express at Vilna railway station. ${ }^{77}$

The letters they sent each other during this time are of considerable length fifteen or more pages are no exception. They are scribbled hastily and on thin paper, which makes reading hazardous. Only the envelopes are marked in clear script (Luba even typed hers) to ensure that they would arrive safely. Luba addressed hers straightforwardly to his parents in the family mansion 'Masud Manzil' in Aligarh. Hamied, by contrast, had to use cover addresses to keep the relationship secret from her parents. Her friends Sonia, Dunia and Estusia in Berlin and Rahel Felman in Vilna took it upon themselves to receive his letters, then forward them in a new envelope with a different sender's name written on the back.

Luba's visit to her parents, under such circumstances, did not go well. Although the whole family waited for her on the platform, the reception was not what she expected:

$76 \quad$ Hamied private archive, Do2015-11-01-(72-89).

77 Hamied private archive, Do2015-11-01-97. 
$\mathrm{Nu}$, everybody was at the station and it was all as it should be after three years of absence. It's just that they were shocked about my appearance. My mother could not stop crying because of that. It made me very sorry. These people have not seen me for three years, so now they think I am too thin, but I feel I have not changed a bit since we last saw each other. I am fed the whole day through and not allowed to do anything but a little walk. I do everything mother tells me because I do not want to upset her any further. ${ }^{78}$

Three years earlier, when Luba had taken herself off to Kaunas, her parents had told her not to return until she had finished her studies and, apart from the obligatory Rosh Hashanah (Jewish New Year) greetings, there had been very little communication between them. When she announced this impending visit, her parents told her not to come. She went anyway, but their unease was palpable: 'at home everything was prepared in a festive manner, but I felt instinctively that something was wrong. ${ }^{79}$ Under these circumstances, she could not find an opening to confess to her mother that she was in love and with whom. When she finally did, they flatly refused to condone the prospect of a union with a foreigner of a different religion. Consequently, when Hamied's letter - after having made its circuitous route from Aligarh to Estusia in Berlin, to Rahel Felman in Vilna, from where it was collected by hand - reached her with the good tiding that his mother supported the marriage plan, she had to write back, 'unfortunately I cannot say that of my own mother'.80

Instead, her father decided on a new direction for her future, according to which she was going to be sent to Manchester to work in a synagogue. Luba naively agreed:

My father, and my mother as well, want me to go to England after my exam to take up a position there. The reason for this is that my father's best friend lives in Manchester, a city in England, and he very much wants me to come. He is the main cantor in a synagogue there and lives in his own villa. Of course, I agreed to this plan. ${ }^{81}$

\footnotetext{
78 Hamied private archive, Do2015-11-01-109. $\mathrm{Nu}$ is the Yiddish equivalent of 'well!' Luba used it so often that Hamied started to use it too.

79 Hamied private archive, Do2015-11-01-109.

8o Hamied private archive, Do2015-11-01-111.

81 Hamied private archive, Do2015-11-01-111.
} 
Upon returning to her familiar surroundings Luba once again became a dutiful daughter. She was the eldest of four siblings and in that role felt responsible. Her letters are full of pride for her little sister Lenka, whom she reports was already playing a role in society, as well as worries about her brother Zorach. Her parents will have put pressure on her to do something meaningful with her life. Little did they realize that this daughter would eventually do what she wanted to do, but would nonetheless support them against all odds. The next year, Lenka became a member of the banned Communist Party and took part in street demonstrations. She was arrested in 1931 and sentenced to four years in a high security prison. On completing her sentence she left Vilna for Russia. ${ }^{82}$ In 1932, her sister Fania, having been expelled from France as an unwanted communist, travelled straight to Moscow without even stopping over in Vilna. Rubin and Pauline were shattered. In Kharkov, Aunt Revekka rejoiced. ${ }^{83}$

In December 1927, however, dissention from the family narrative was still unthinkable. The Derczanskis, facing their stubborn eldest, suggested a sensible Jewish solution. In their letters, Luba and Hamied even toyed with the idea of 'Manchester'. Hamied declared he would move there if Luba was to be offered a fixed position, 'otherwise, stay in Berlin and learn English. You won't experience any money problems as long as Hamied lives there'. ${ }^{84}$ His words soothed her. Upon returning, Luba looked for an English teacher and also moved out of her neighbourhood. Too many friends, too many distractions, she wrote to Hamied..$^{85}$ Instead, she found a room far from the city centre, in the vicinity of her school, where she withdrew to make it through the forthcoming exams and prepare for an independent job. When Hamied returned to Europe in May 1928, she wrote that she could not come to Paris because of the exams. ${ }^{86}$ In June, he came to Berlin instead where they married in the Ahmadiyya mosque. However, she waited until August before she sent her parents a telegram with the news. ${ }^{87} \mathrm{~A}$ year later, they were ready to receive Hamied, who recorded their first meeting in his memoir:

I cannot forget the scene at the station where Luba's father, mother, uncles and aunties, her brother, Zorach, and sisters were anxiously waiting to see who their daughter had married. Perhaps they thought that their

82 Archiwum Akt Nowych (Warsaw), entry Derczanska, Helena, CA KC 9292, Z. (abstract based on police files).

83 Hamied private archive, DO2015-11-05-06.

84 Hamied private archive, DO2015-11-02-05.

85 Hamied private archive, DO2015-11-02-06.

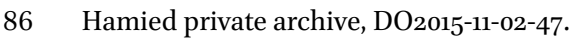

87 Hamied private archive, DO2015-11-02-75. 
son-in-law would be a dark looking type of Indian. As we alighted from the train, I could see how happy they felt in greeting their son-in-law, who was very well dressed and was fair and quite handsome. ${ }^{88}$

Hamied had his own interpretation of the family tension, which he translated into the Indian preoccupation with skin colour. ${ }^{89}$ Yet, colour seems to have been the least of their worries. What the Derczanskis struggled with was the right degree of modernity. Luba only managed to bridge the disagreement through repeating the marriage ceremony in the choral synagogue in Vilna. No photographs or documents survived this event, but family lore did and it suffices to say that it confirmed her skills as a bridge builder. Returning to Vilna in 1927, she discovered the chasm between central European Judaism and her own, still fresh, experience of the Indian-Jewish entanglement. Her reconciliation with her family allowed her to remain her father's daughter and keep true to her family roots. Hamied detected the compromise. From his Indian perspective, in which pedigree occupied a central place, he observed: 'I believe Luba inherited all her fine and noble character from her father and this has made her popular, not only in my family but among the vast number of my friends all over India'.90 Incidentally, the metamorphosis of this 'modern Russian woman' was very different from the one described in Chapter 1. Neither she nor Hamied anchored themselves in Berlin in ways that would have rendered them Berliners. Holding onto his Indian identity, Hamied returned to 'Hindustan'. His idea of a future India involved a shared space in which every religious group, whether Muslim or Hindu, Sikh, Jain, or Jew, would enjoy an equal share of state services and equal representation in the public sphere. In this scheme of things, Luba's place was prepared, and she, for her part, was ready to become an Indian woman.

In April 1932, after three years of living in poorly furnished rented rooms in Bombay, trying to make a living selling potency pills in the Far East for which Hamied had acquired the rights in Berlin, the couple had finally saved up enough money to pay for a sea passage to Europe. She badly wanted to visit her

\footnotetext{
88 Hamied, A Life to Remember, 85 .

89 An early testimony of this preoccupation is found in Mirza Sheikh I'tesammudin, Wonders of Vilayet, translated by Kaiser Haq (New Delhi: Chronicle Books, 2008). See also Haq's own observations on pp. $\mathrm{xv}-\mathrm{xvi}$.

9o Hamied, A Life to Remember, 86.
} 
parents in Vilna, while he needed to see his business partners. ${ }^{91}$ In Berlin, they stayed with Aunt Bertha. It was during this period that the film, described at the beginning of this chapter, was shot, featuring a self-conscious Luba, a beaming Hamied, Aunt Bertha, and Bertha's husband, Arthur Tänzler. The latter poses in the screenshots as a benevolent gentleman with a balding head and round rimless spectacles and, as I mentioned earlier, the car was his. They will have wanted to show the Indian family what Berlin had to offer. The most important tool for this, the hand camera that followed their every move, remains invisible. Cameras for amateur use that could be held with one hand and that could follow moving objects in the street were at that time state of the art, and they were still very expensive. ${ }^{92}$ Uncle Arthur no doubt owned the camera too, but it was clearly Luba who directed the script.

These were global citizens at home in the different capitals of the world, with access to the latest technology and equipped with the knowledge of how to behave as a modern couple. Another strip of film shot some days after the Berlin scene shows them in bathing costumes and in the company of another German-Indian couple. This time the place of action is the beach; the men are pushing the women towards the edge of the water and the women are laughing into the camera..$^{93}$ Here is another example of globalization at close range, for modernity had devised a wholly new type of man and woman, which in the East and West, in Bombay and Berlin, spoke to the imagination of the middle classes. Indeed, between 1924 when she left Vilna, and 1932 when she returned with her husband to the place of her first love, Luba had moved from one station to the next. She had moved from her Jewish home and communist commitments in Vilna, to a Yiddish setting in Kaunas, to communist friends and a refuge in the German Jewish milieu of Berlin, to her entanglement with an Indian lover and involvement in the cause of Indian independence, and she took something from each encounter as she made her way in the world.

This is not the place to discuss the details of Luba Hamied's life in Bombay, of the support she gave her husband's business, of her daily life and the small things she did to create a shared space for Hindus and Muslims, of her desperate search for her parents after the war only to discover that they had been murdered by the Germans - that part of her life will be addressed elsewhere. To conclude, however, it is important to recognize that she managed to keep a balance between the Indian and Russian sides of her family. This was a rare

91 Hamied, A Life to Remember, 107.

92 Emanuel Goldberg and Joris Ivens, 'The Kinamo movie camera', Film History: An International Journal (20 (1), 2008), 49-58.

93 'Old Family Film Part 1', Hamied private archive. 


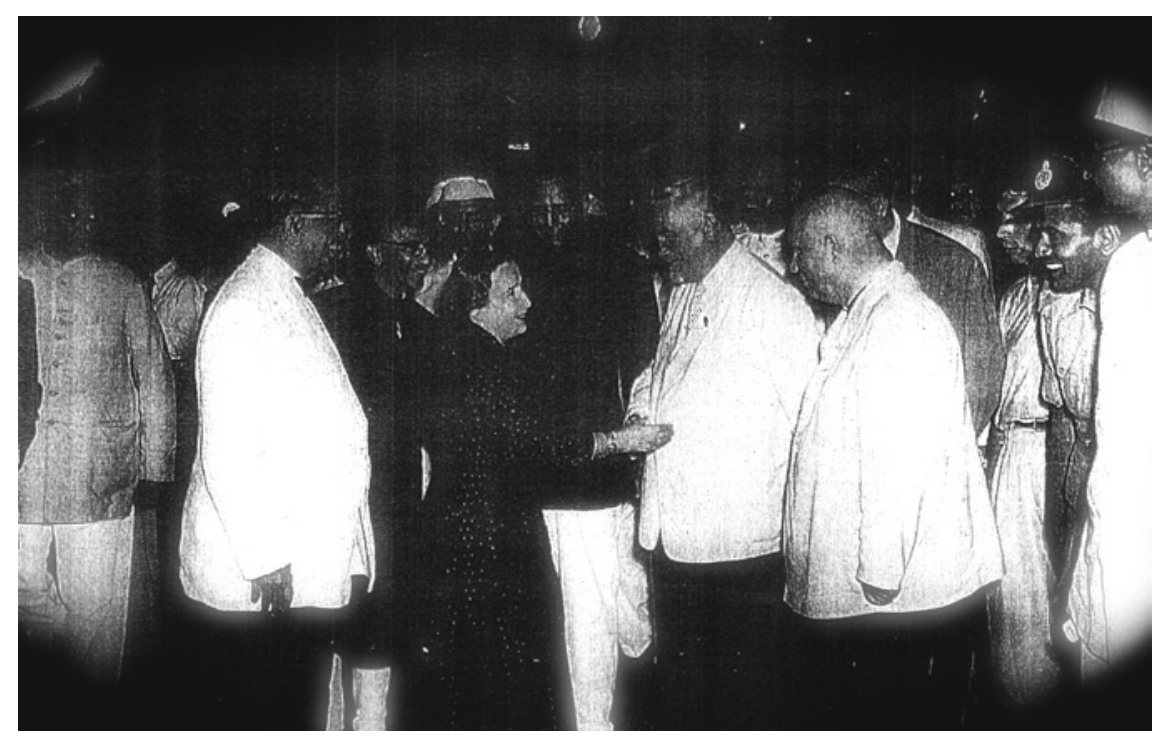

FIGURE 6.3. Luba with Bulganin and Khruhchev in Bombay, 1953

gift, which later in life she was able to extend to include the Indian and Russian heads of state. A photograph in the family collection serves as testimony (Figure 6.3). ${ }^{94}$

In 1956, once India had gained independence and established itself as a non-aligned state, President Nehru invited the prime minister of the Soviet Union Nikolai Bulganin and the secretary of the Communist Party Nikita Khrushchev on a formal visit in the hope of establishing relations between their respective countries. The photograph shows Luba Hamied stepping forward to grasp Bulganin's hand. Whatever she said at that decisive moment must have been beguiling, for the Russians are clearly enchanted, and not only they. Thus, the Russian girl from Jewish Vilna had furthered India's interests while at the same time connecting to her home base. As everything else, that too was a result of globalization.

94 Hamied private archive, Marina Suzman collection. Cf. https://www.bulganinandkhrush chevvisittoindia. 